\title{
Effect of In Ovo Feeding of L-Glutamine to Chick Embryos*
}

http://dx.doi.org/10.1590/1806-9061-2018-0852

\section{-Author(s)}

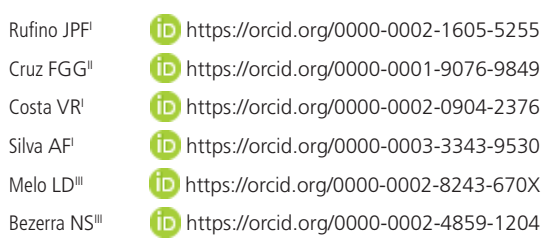

Graduate Program in Animal Science, College of Agrarian Sciences, Federal University of Amazonas, Manaus, Amazonas, Brazil.

" Department of Animal and Vegetable Production College of Agrarian Sciences, Federal University of Amazonas, Manaus, Amazonas, Brazil.

III Animal Science Course, College of Agrarian Sciences, Federal University of Amazonas, Manaus, Amazonas, Brazil.

*Part of master's degree dissertation of the first author.

\section{-Mail Address}

Corresponding author e-mail address João Paulo Ferreira Rufino

Federal University of Amazonas - Dept. of Animal and Vegetable Production - Av. General Rodrigo Octávio Jordão Ramos number 3000 Neighborhood Coroado I MANAUS Amazonas, Brazil 69077-000. Email: bernardorfnogueira@gmail.com

\section{- Keywords}

Aminoacid, biotechnology, embryo mortality, hatchability, in ovo feeding.

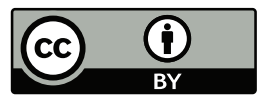

Submitted: 16/April/2019

Approved: 10/September/2019

\section{ABSTRACT}

In ovo feeding (IOF), injecting nutrients into the amnion of the avian embryo may enhance hatchability, gastrointestinal development and serum metabolism changes. This hypothesis was evaluated with 5 IOF solutions containing L-glutamine. Were used 315 fertile Rhode Island Red eggs were used (breeders with 32-weeks). The experimental design was completely randomized with the treatments constituted by two controls and five solutions containing L-glutamine levels with 45 replicates each. Data collected were subjected to polynomial regression at $5 \%$ of significance. Differences ( $p>0.05)$ were observed in hatchability and intermediary mortality, with a gradual lower of decrease in hatchability from the IOF of L-glutamine. The yolk sac was higher $(p<0.05)$ after the IOF (control and L-glutamine) in the in ovo fed embryos at $0.5 \%$ L-glutamine. IOF of L-glutamine alone enhanced the blood $\mathrm{pH}$ and reduced the other serum parameters $(p<0.05)$, which may have fuelled more embryo development, mainly vital organs how as the heart and the liver due to the larger concentration of available nutrients for the embryo. The results of this study indicate that until $0.5 \%$ L-glutamine may be supplemented in-ovo to chick embryos without negative influence on chick weight and gastrointestinal tract development, acting as serum biochemical metabolism regulator and obtaining better hatchability.

\section{INTRODUCTION}

During the incubation period and in the first hours after hatching, the birds have limited digestive functions, which reduces the nutrients availability to growth metabolism and restricts the digestive capacity that begins the development when the amniotic fluid is orally consumed at $17 \mathrm{~d}$ of incubation (Uni et al., 2005).

And even the egg composition being considered complete, in nutritional terms, the percentages of amino acids, carbohydrates, vitamins, minerals and lipids are sufficient only in the initial phase (1 to 7 days) of the incubation period, being below the required levels in the final phase (15 to 21 days) and during the hatching (Gonzales et al., 2013).

The IOF in the pre-hatching phase is a recent technology in poultry industry. This method of supplementing for oviparous species, described within the US Patent $(6,592,878)$ of Uni \& Ferket $(2003)$, involves the administration of exogenous nutrients into the amnion of the developing embryo of chickens and turkeys at about 17 and $23 \mathrm{~d}$ of incubation, respectively (Foye et al., 2006).

These substances as nutritional supplements aim to improve the initial development of the gastrointestinal tract and boost the digestive enzymes and a greater growth of villi (Geyra et al., 2001). 
In this context, the IOF using aminoacids already proved to beviable (Ohtaet al., 1999), improving the chick weight at birth by increasing the availability of aminoacid (Ohtaet al., 2001) used by the embryo (AlMurrani, 1982). However, there are few studies on IOF regarding the use of glutamine in broiler breeder hen eggs (Salmanzadeh et al., 2016).

Glutamine is the principle metabolic fuel for development of the gastrointestinal tract (Andrew $\&$ Griffiths, 2002). This amino acid can generate 30 moles of ATP, source of energy almost as important as glucose for these cells (Lacey \& Wilmore, 1990; Hall et al., 1996; Vieira et al., 2006). Besides, glutamine may increase intestinal villus height and consequently, improve growth performance of broilers (Bartell \& Batal,2007; Yi et al., 2005; Jazideh et al., 2014)

All these beneficial actions of glutamine in particular, make it an amino acid deserving of scientific and technical attention (Salmanzadeh et al., 2016). Thus, the present study examined the hypothesis that IOF of L-glutamine may accelerate the development of the gastrointestinal tract, affect the hatchability and serum biochemical metabolism of chicks.

\section{MATERIAL AND METHODS}

This study was conducted at the Laboratory of Poultry Technology, Poultry Sector, Department of Animal and Vegetable Production (DPAV), College of Agrarian Sciences (FCA), Federal University of Amazonas (UFAM), South Sector at the University Campus, Manaus, State of Amazonas, Brazil.

The experimental procedures were conducted in accordance with the ethical principles for animal experimentation adopted by the Brazilian College of Animal Experimentation (COBEA) and the experimental procedures were approved by the local Committee for Ethical Animal Use (CEUA - protocol n. 016/2016) of Federal University of Amazonas, Manaus, AM, Brazil.

315 fertile Rhode Island Red eggs were used (breeders with 32-weeks). A completely randomized design was applied, with the treatments (Table 1) constituted by two controls and five solutions containing L-glutamine levels with 45 replicates (eggs) each. The L-glutamine used was manufactured by Midway International Labs $\mathrm{Ltda}^{\odot}$ and denominated as pure and micronized.

All eggs were collected at one time, being weighed in room temperature, and distributed in trays in an incubator machine PETERSIME 168 with $37.6{ }^{\circ} \mathrm{C}$ temperature, $66 \%$ relative humidity and turn of eggs in one hour intervals. The eggs were randomly
Table 1 - Experimental solutions with L-glutamine.

\begin{tabular}{lcc}
\hline Treatments & Solutions & Osmolarity $(\mathrm{mOsm} / \mathrm{L})$ \\
\hline Control & Intact egg & - \\
IOF Control & $0.5 \% \mathrm{NaCl}+0.0 \%$ L-glutamine & 170.94 \\
Solution 1 & $0.5 \% \mathrm{NaCl}+0.5 \%$ L-glutamine & 239.37 \\
Solution 2 & $0.5 \% \mathrm{NaCl}+1.0 \%$ L-glutamine & 307.80 \\
Solution 3 & $0.5 \% \mathrm{NaCl}+1.5 \%$ L-glutamine & 376.23 \\
Solution 4 & $0.5 \% \mathrm{NaCl}+2.0 \%$ L-glutamine & 444.66 \\
Solution 5 & $0.5 \% \mathrm{NaCl}+2.5 \%$ L-glutamine & 513.10 \\
\hline
\end{tabular}

distributed, and after analysis to fertility confirmation at 16 days of incubation, they were separated in 45 units per treatment.

All eggs were kept out of the incubator machine for 1:30 hours due to inoculation procedures in the selected treatments. The room temperature used for inoculation was $37{ }^{\circ} \mathrm{C}$ and $65 \%$ of air humidity, in order to preserve the embryo's integrity.

Fertile eggs were sanitized and drilled in the air chamber region (avoiding to drill the inner membrane of the eggshell). The solutions (temperature of $26.7^{\circ}$ C) were injected $(0.5 \mathrm{~mL})$ into the amniotic fluid (methodology previously tested) using needle syringes $(7 \times 2.5 \mathrm{~mm})$. The holes in the egg shells were closed using melted paraffin and the eggs transferred to hatching machine PETERSIME 168 with $36.6{ }^{\circ} \mathrm{C}$ temperature, $76 \%$ relative humidity at 21 days of incubation ( $504 \pm 2$ hours).

After birth, the \% of hatchability (birth chicks/ fertile eggs), \% of intermediary mortality (dead embryos among 16 and 18 days of incubation), \% of late mortality (dead embryos among 19 and 21 days of incubation without pecked the eggshell), \% of pipped eggs (dead embryos among 19 and 21 days of incubation that pecked the eggshell) and chick weight and chick/egg correlation were evaluated.

Regarding hatchability results, five able chicks of each treatment were selected for analysis. Blood was collected from the birds heart for analysis of biochemical serum parameters (glucose $(\mathrm{mg} / \mathrm{dl})$, triglycerides (mg/ $\mathrm{dl})$, cholesterol $(\mathrm{mg} / \mathrm{dl})$ and $\mathrm{pH})$ using a portable biochemical analyser (Accucheck Trend, ROCHE@) and a pH meter (SENTRON, model 1001) coupled to a finetip penetration probe (SENTRON type LanceFET, model 1074-001).

Then, the same chicks were slaughtered by cervical dislocation for evaluation of heart $(\mathrm{g})+$ gastrointestinal tract development: yolk sac $(\mathrm{g})$, liver $(\mathrm{g})$, pancreas $(\mathrm{g})$, pro-ventricle (g), gizzard (g), digestive system length $(\mathrm{cm})$, oropharynx + oesophagus $(\mathrm{cm})$, duodenal loop $(\mathrm{cm})$, jejunum + ileum $(\mathrm{cm})$, cecum $(\mathrm{cm})$ and colon + rectum $(\mathrm{cm})$. 
Statistical analysis was performed using the software Statistical Analysis System (2008) and estimates of treatments were subjected to polynomial regression at $5 \%$ of significance.

\section{RESULTS}

Differences ( $p>0.05)$ were observed in hatchability $\left(y=106.60+1.566 x-2.0631 x^{2} ; R^{2}=0.86\right)$ and intermediary mortality $\left(y=33.717+17.267 x ; R^{2}=\right.$ $0.86)$ results, with a gradual decrease in hatchability from the IOF of L-glutamine, and consequently, increase in the embryo mortality, mainly intermediate (hours after IOF procedures) (Table 2).

In this study, it was possible to determine the embryo physiological limit point from the increasing IOF of L-glutamine addition (Figure 1).

Table $\mathbf{2}$ - The effects of IOF of L-glutamine on hatchability and embryo mortality.

\begin{tabular}{|c|c|c|c|c|c|c|}
\hline Treatments & $\begin{array}{c}\text { Hatchability } \\
(\%)\end{array}$ & $\begin{array}{c}\text { Intermediary } \\
\text { mortality } \\
(\%)\end{array}$ & $\begin{array}{c}\text { Late } \\
\text { mortality } \\
(\%)\end{array}$ & $\begin{array}{l}\text { Pipped } \\
\text { eggs } \\
(\%) \\
\end{array}$ & $\begin{array}{l}\text { Chick } \\
\text { weight } \\
\text { (g) }\end{array}$ & $\begin{array}{l}\text { Chick-Egg } \\
\text { Correlation }\end{array}$ \\
\hline Control & 93.28 & 0.00 & 4.45 & 2.27 & 32.11 & 0.59 \\
\hline IOF Control & 100.00 & 0.00 & 0.00 & 0.00 & 33.35 & 0.62 \\
\hline $0.5 \mathrm{NaCl}+0.5$ Glut. & 97.82 & 2.18 & 0.00 & 0.00 & 33.07 & 0.66 \\
\hline $0.5 \mathrm{NaCl}+1.0$ Glut. & 79.94 & 13.44 & 6.62 & 0.00 & 32.70 & 0.62 \\
\hline $0.5 \mathrm{NaCl}+1.5$ Glut. & 19.86 & 69.22 & 9.80 & 1.12 & 31.88 & 0.62 \\
\hline $0.5 \mathrm{NaCl}+2.0$ Glut. & 15.98 & 71.42 & 10.80 & 1.80 & 33.46 & 0.61 \\
\hline $0.5 \mathrm{NaCl}+2.5$ Glut. & 6.62 & 81.20 & 12.18 & 0.00 & 33.60 & 0.61 \\
\hline$p$-value & 0.01 & 0.01 & 0.01 & 0.57 & 0.70 & 0.01 \\
\hline Effect & $\mathrm{Q}$ & PL & $\mathrm{PL}$ & ns & ns & $\mathrm{Q}$ \\
\hline CV (\%) & 7.02 & 11.68 & 14.75 & 16.64 & 5.77 & 5.95 \\
\hline
\end{tabular}

CV - Coefficient of variation. p-value - Coefficient of probability. Q - Quadratic. PL-Positive Linear. ns - non significant.

However, IOF embryos (IOF Control and 0.5\% L-glutamine) showed higher hatchability than the control group (without IOF), with lower $(p<0.05)$ late mortality $\left(y=1.5343+1.9496 x ; R^{2}=0.70\right)$ and better $(p<0.05)$ chick-egg correlation $(y=0.6929+0.0055 x$ $\left.-0.0038 x^{2} ; R^{2}=0.79\right)$.

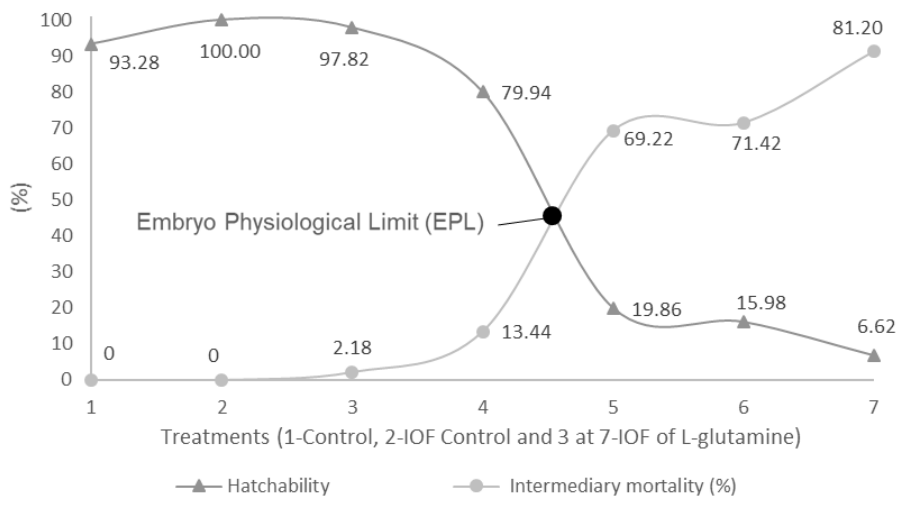

Figure 1 - The behaviour of IOF of L-glutamine on hatchability and intermediary mortality. All data represent the mean value per treatment. The meeting of curves between 1.0 and $1.5 \%$ IOF of L-glutamine determines the embryo physiological limit point.

The yolk sac $\left(y=7.235+0.5113 x-0.3616 x^{2} ; R^{2}\right.$ $=0.85)$ was higher $(p<0.05)$ after the IOF (control and L-glutamine) in the in ovo fed embryos at $1.0 \%$ L-glutamine, whereas all IOF embryos exhibited greatest $(p<0.05)$ abilities regarding heart development $\left(y=0.2487+0.0209 x ; R^{2}=0.89\right)$ compared with the control groups (Table 3).
No significant effect ( $p>0.05)$ of the IOF treatments was observed in the gastrointestinal tract development. However, there was increase in several organs and compartments of gastrointestinal tract of in ovo fed embryos (Table 3 and Table 4, respectively).

Chicks from embryos in ovo fed L-glutamine had greater $(p<0.05)$ blood $\mathrm{pH}(\mathrm{y}=7.159+0.02987 \mathrm{x}$ $\left.0.0202 x^{2} ; R^{2}=0.83\right)$, whereas all in ovo embryos exhibited lower $(p<0.05)$ triglycerides concentration (y $\left.=283.63-18.371 x ; R^{2}=0.82\right)$, and significant changes $(p<0.05)$ in glucose $\left(y=225.8+3.846 x-3.125 x^{2} ; R^{2}\right.$ $=0.83)$ and cholesterol concentrations $(y=173.05+$ $\left.7.898 x-2.4732 x^{2} ; R^{2}=0.85\right)$.

In summary, IOF of L-glutamine alone enhanced the blood $\mathrm{pH}$ and reduced the other serum parameters (Table 5), which may have fueled more embryo development, mainly vital organs as heart, liver and pancreas due to the larger concentration of available nutrient for embryo.

\section{DISCUSSION}

Concerning hatchability and gastrointestinal development, the IOF Control and 0.5\% L-glutamine presented better results. Based on positive preliminary studies with aminoacids, the IOF solution formulation was developed to increase the available nutrients 
Table 3 - The effects of IOF of L-glutamine on heart and gastrointestinal development of post-hatch chicks.

\begin{tabular}{|c|c|c|c|c|c|c|}
\hline Treatments & $\begin{array}{c}\text { Yolk sac } \\
(\mathrm{g})\end{array}$ & $\begin{array}{l}\text { Heart } \\
\text { (g) }\end{array}$ & $\begin{array}{l}\text { Liver } \\
\text { (g) }\end{array}$ & $\begin{array}{c}\text { Pancreas } \\
\text { (g) }\end{array}$ & $\begin{array}{c}\text { Pro-ventricle } \\
\text { (g) }\end{array}$ & $\begin{array}{c}\text { Gizzard } \\
\text { (g) }\end{array}$ \\
\hline Control & 4.10 & 0.25 & 0.73 & 0.03 & 0.32 & 1.84 \\
\hline IOF Control & 4.99 & 0.31 & 0.77 & 0.01 & 0.30 & 1.76 \\
\hline $0.5 \mathrm{NaCl}+0.5$ Glut. & 7.16 & 0.32 & 0.76 & 0.02 & 0.28 & 1.83 \\
\hline $0.5 \mathrm{NaCl}+1.0$ Glut. & 5.33 & 0.33 & 0.71 & 0.01 & 0.26 & 1.60 \\
\hline $0.5 \mathrm{NaCl}+1.5$ Glut. & 3.85 & 0.35 & 0.97 & 0.01 & 0.32 & 1.93 \\
\hline $0.5 \mathrm{NaCl}+2.0$ Glut. & 3.61 & 0.37 & 0.90 & 0.03 & 0.31 & 1.67 \\
\hline$p$-value & 0.05 & 0.05 & 0.29 & 0.23 & 0.77 & 0.76 \\
\hline Effect & $\mathrm{Q}$ & $\mathrm{PL}$ & ns & ns & ns & ns \\
\hline CV (\%) & 18.45 & 18.80 & 14.59 & 13.26 & 15.06 & 11.62 \\
\hline
\end{tabular}

CV - Coefficient of variation. $p$-value - Coefficient of probability. Q - Quadratic. PL - Positive Linear. ns - non significant.

Table 4 - The effects of IOF of L-glutamine on gastrointestinal development of post-hatch chicks.

\begin{tabular}{|c|c|c|c|c|c|c|}
\hline Treatments & $\begin{array}{c}\text { Gastrointestinal } \\
\text { tract } \\
(\mathrm{cm})\end{array}$ & $\begin{array}{c}\text { Oropharynx }+ \\
\text { oesophagus } \\
(\mathrm{cm})\end{array}$ & $\begin{array}{l}\text { Duodenal loop } \\
\qquad(\mathrm{cm})\end{array}$ & $\begin{array}{l}\text { Jejunum + ileum } \\
\qquad(\mathrm{cm})\end{array}$ & $\begin{array}{l}\text { Cecum } \\
(\mathrm{cm})\end{array}$ & $\begin{array}{l}\text { Colon + } \\
\text { rectum } \\
(\mathrm{cm})\end{array}$ \\
\hline Control & 47.00 & 6.80 & 7.00 & 22.52 & 6.96 & 5.28 \\
\hline IOF Control & 47.40 & 6.80 & 7.20 & 27.90 & 7.38 & 3.96 \\
\hline $0.5 \mathrm{NaCl}+0.5$ Glut. & 42.30 & 6.40 & 6.42 & 17.84 & 6.40 & 3.78 \\
\hline $0.5 \mathrm{NaCl}+1.0$ Glut. & 43.40 & 6.10 & 6.00 & 25.20 & 6.20 & 5.14 \\
\hline $0.5 \mathrm{NaCl}+1.5$ Glut. & 43.10 & 5.80 & 5.60 & 22.60 & 6.28 & 4.14 \\
\hline $0.5 \mathrm{NaCl}+2.0$ Glut. & 44.80 & 6.30 & 6.50 & 23.50 & 7.66 & 4.92 \\
\hline$p$-value & 0.61 & 0.35 & 0.29 & 0.07 & 0.29 & 0.11 \\
\hline Effect & ns & $\mathrm{ns}$ & ns & ns & ns & ns \\
\hline CV (\%) & 12.53 & 19.84 & 18.18 & 11.07 & 17.72 & 17.58 \\
\hline
\end{tabular}

CV - Coefficient of variation. $p$-value - Coefficient of probability. ns - non significant.

Table $\mathbf{5}$ - The effects of IOF of L-glutamine on serum biochemical parameters of post-hatch chicks.

\begin{tabular}{lllll}
\hline Treatments & $\begin{array}{l}\text { Glucose } \\
(\mathrm{mg} / \mathrm{dl})\end{array}$ & $\begin{array}{l}\text { Triglycerides } \\
(\mathrm{mg} / \mathrm{dl})\end{array}$ & $\begin{array}{l}\text { Cholesterol } \\
(\mathrm{mg} / \mathrm{dl})\end{array}$ & $\mathrm{pH}$ \\
\hline Control & 194.50 & 292.00 & 163.50 & 6.91 \\
\hline IOF Control & 185.50 & 242.50 & 169.00 & 6.94 \\
$0.5 \mathrm{NaCl}+0.5$ Glut. & 221.00 & 199.50 & 178.00 & 7.12 \\
$0.5 \mathrm{NaCl}+1.0$ Glut. & 209.50 & 194.50 & 178.00 & 7.08 \\
$0.5 \mathrm{NaCl}+1.5$ Glut. & 197.50 & 194.00 & 163.00 & 6.99 \\
$0.5 \mathrm{NaCl}+2.0$ Glut. & 191.50 & 193.50 & 160.00 & 7.01 \\
\hline$p$-value & 0.05 & 0.01 & 0.01 & 0.01 \\
\hline Effect & $\mathrm{Q}$ & $\mathrm{NL}$ & 2.04 & $\mathrm{Q}$ \\
\hline $\mathrm{CV}(\%)$ & 8.34 & 8.40 & 0.47 \\
\hline
\end{tabular}

CV - Coefficient of variation. $p$-value - Coefficient of probability. Q - Quadratic. NL - Negative Linear.

concentration, providing a better development for the chicks (Foye et al., 2007).

On the other hand, Pedroso et al. (2006) and Dos Santos et al. (2010) did not report the effect of IOF of glutamine in the amniotic fluid of embryos on hatchability. However, Salmanzadehet al. (2016) showed that the hatchability was significantly reduced when injecting glutamine at days 7 of incubation.

Uni et al. (2005) comments that IOF to chicken embryos at the final stage of incubation may provide better effects than at initial stages, including the increase in hatchability. Besides the significant difference in hatchability among the in ovo injected groups observed in this study, other studies (Salmanzadeh et al., 2016), indicated that nutrient specificity and varied osmolarity of the injection might result in differing response of embryos.

Another important question about IOF, is the socalled embryo physiological limit, that corresponds to the meeting of graphic curves of hatchability and intermediate embryo mortality. This point represents the limit of the embryo organism in accepting the exogenous nutrient, substance or solution, mainly due to the clash among their osmolarities. 
According to Uni and Ferket (2003), solutions at high exogenous nutrients concentrations may affect egg osmotic balance, and consequently embryo development, suggesting that the lower hatchability and high intermediary mortality of the high level amino acid-injected eggs, as was verified in the results obtained in this study, could be caused by osmotic balance changes.

At the same time, the IOF amino acids stimulate the structural development, providing heavier chicks with greater development of gastrointestinal tract and yolk sac, mainly in the intestinal area (villi and cryptes) to increase the nutrients absorption area. Hence, the in ovo fed avian neonate may have a greater capacity to digest and absorb nutrients from an exogenous diet relative to the conventional hatchling (Tako et al., 2004).

Depending of the profile of the exogenous nutrients supplied to the embryo, there will be different embryo answers reflected in this post-IOF development. The IOF of $\mathrm{CHO}$, from results of several studies, may accelerate gut development and maturity, serving as a tool to overcome growth constraints imposed by limited digestive capacity in hatchlings by enhancing intestinal function and maturation prior to hatching (Tako et al., 2004; Foye et al., 2006; Leitão et al., 2010; Leitão et al., 2014).

These amino acids would have been absorbed by the muscles due to the action of insulin and incorporated into protein (Foye et al., 2006). Studies have shown that dietary amino acids are important signalling mediators in pancreatic $\beta$-cell insulin secretion in vitro and release of insulin-like growth factors in vivo (Xu et al., 1998), and that the amino acid reserves present in the yolk sac are insufficient to meet the requirements for growth process of birds, especially in the final period of embryonic development and first $72 \mathrm{~h}$ posthatch (Ohta et al., 2004).

Previous studies reported by Chen et al. (2009) and Salmanzadeh et al. (2016) presented that IOF of glutamine may be seen as an effective tool to improve the mean bodyweights of newly hatched chickens. The IOF of glutamine present a positive relationship between protein synthesis and amino acid concentration (Jepson et al., 1988; Welborne, 1995, Maiorka et al., 2000; Silva et al., 2007), and affinity with growth hormone (Ray et al., 2003) that synthesis begins in the embryonic stage (Harvey et al., 2001). Vieira \& Moran (1998) affirm that yolk sac contains approximately $150 \mathrm{mg}$ of glutamine, but this amount is not enough to meet the embryo requirements for ideal development.

In this context, Al-Murrani (1982) and Ohta et al. (2001) observed that the injection of amino acids increased the available of the amino acid contents for the embryos, increasing the yolk sac, and the embryonic body weight. The same authors also affirm that the benefits of adding external nutrients to hatching eggs illustrate the limitations of avian species, which, unlike mammals, do not have a continuous energy supply from a maternal source to support embryonic and neonatal growth. However, AlMurrani (1982), John et al. (1988), Ohta et al. (2001), and Uni et al. (2005) comment that injected nutrients are not directly exposed to embryonic intestine when it is most needed, near the end of incubation, being firstly allocated in attached structures, as the yolk sac, amniotic fluid and others, and only after will be moved to embryo's organism.

The IOF, that is fundamentally feeding to the avian embryo, maycircumvent the growth constraintsimposed by limited gut function in the avian neonate by the oral consumption of enteric modulators (compounds that stimulate development or metabolism of the cells of the digestive system) administered in the amnionic fluid of the avian embryo, which may enhance the gut capacity to absorb and digest dietary nutrients during late-term embryonic development (Uni \& Ferket, 2003; Tako et al., 2004; Foye et al., 2007).

Our data also implies that L-glutamine in ovo supplementation may act as an enteric modulator that enhances intestinal absorption, and as a serum metabolism regulator due to the significant heart development and changes in blood parameters. Numerous studies have demonstrated that the intestinal amino acid (Karasov et al., 1987; Torras-Llort et al., 1998) and glucose transporters (Diamond \& Karasov, 1987; Karasov et al., 1987; Solberg \& Diamond, 1987; Buddington \& Diamond, 1989; Ferraris \& Diamond, 1989; Ferraris et al., 1992) are upregulated in the presence of increasing concentrations of their specific dietary substrate(s).

The increase of these glucose transporters, once there is osmotic equilibrium between the inoculated solution and the organism of the embryo, will provide an increase in glucose concentration in the bloodstream (Lu et al., 2005; Uni et al., 2005), as was verified in our results for inoculation of $0.5 \%$ glutamine. This same relation applies to other transporters and nutrients that act directly on energy metabolism (Uni et al., 2005). 


\section{CONCLUSIONS}

The results of this study indicate that until $0.5 \%$ L-glutamine may be supplemented in ovo to chick embryos without negative influence on chick weight and gastrointestinal tract development, acting as a biochemical metabolism serum regulator and obtaining better hatchability.

\section{REFERENCES}

Al-Murrani WK. Effect of injecting amino acids into the egg on embryonic and subsequent growth in the domestic fowl. British Poultry Science 1982;23(2):171-174

Andrews FJ, Griffiths RD. Glutamine: essential for immunenutrition in the critically ill. British Journal of Nutrition 2002;1:3-8.

Bartell SM, Batal AB. The effect of supplemental glutamine on growth performance, development of the gastrointestinal tract, and humoral immune response of broilers. Poultry Science 2007;86:1940-1947.

Buddington RK, Diamond JM. Ontogenetic development of intestinal nutrient transporters. Annual Review of Physiology 1989;51:601-619.

Chen $\mathrm{W}$, Wang R, Wan HF, Xiong $X L$, Peng P, Peng J. Influence of in ovo injection of glutamine and carbohydrates on digestive organs and pectoralis muscle mass in the duck. British Poultry Science 2009;50(4):436-442.

Diamond JM, Karasov $\mathrm{WH}$. Adaptive regulation of intestinal nutrient transporters. Proceedings of the National Academy of Sciences USA 1987;84:2242-2245.

Ferraris RP, Diamond JM. Specific regulation of intestinal nutrient transporters by their dietary substrates. Annual Review of Physiology 1989;51:125-141.

Ferraris RP, Villenas SA, Hirayama BA, Diamond JM. Effect of diet on glucose transporter site density along the intestinal crypt-villus axis. American Journal of Physiology 1992;262:1060-1068.

Foye OT, Uni Z, Ferket PR. Effect of in ovo feeding egg white protein, $\beta$-hydroxy- $\beta$-methylbutyrate, and carbohydrates on glycogen status and neonatal growth of turkeys. Poultry Science 2006;85(7):11851192.

Foye OT, Uni Z, Ferket PR. The Effects of in ovo feeding arginine, $\beta$-hydroxy$\beta$-methyl-butyrate, and protein on jejunal digestive and absorptive activity in embryonic and neonatal turkey poults. Poultry Science 2007;86(12):2343-2349.

Geyra A, Uni Z, Sklan, D. Enterocyte dynamics and mucosal development in the posthatch chick. Poultry Science 2001;80(6):776-782.

Gonzales E, Cruz CP, Leandro NSM, Strighini JH, Brito AB. In Ovo Supplementation of $25(\mathrm{OH}) \mathrm{D}_{3}$ to Broiler Embryos. Brazilian Journal of Poultry Science 2013;15(3):169-286.

Hall JC, Heel K, McCauley R. Glutamine. British Journal of Surgery 1996;83:305-331.

Harvey S, Johnson CDM, Sanders EJ. Growth hormone in neural tissue of the chick embryo. Journal of Endocrinology 2001;169(3):487-496.

Jazideh F, Farhoomand P, Daneshyar M, Najafi G. The effects of dietary glutamine supplementation on growth performance and intestinal morphology of broiler chickens reared under hot conditions. Turkish Journal of Veterinary and Animal Sciences 2014;38:264-270.
Jepson MM, Bates PC, Broadbent P, Pell JM, Millward DJ. Relationship between glutamine concentration and protein synthesis in rat skeletal muscle. American Journal of Physiology 1988;255(2):166-172.

John TM, George JC, Moran Jr ET. Metabolic changes in pectoral muscle and liver of turkey embryos in relation to hatching: influence of glucose and antibiotic treatment of eggs. Poultry Science 1988;67:463-469.

Karasov WH, Solberg DH, Diamond JM. Dependence of intestinal amino acid uptake on dietary protein or amino acid levels. American Journal of Physiology 1987(5);252:614-625.

Lacey JM, Wilmore DW. Is glutamine a conditionally essential amino acid? Nutrition Review 1990;48:297-309.

Leitão RA, Leandro NSM, Stringhini JH, Café MB, Andrade MA. Inoculação de maltose, sacarose ou glicose em ovos embrionados de baixo peso. Acta Scientiarum. Animal Sciences 2010;32(1):93-100.

Leitão RA, Leandro NSM, Stringhini JH, Café MB, Matos MS, Andrade MA. Inoculação de maltose e/ou sacarose em ovos leves embrionados. Ciência Animal Brasileira 2014;15(1):55-63.

Lu JW, McMurtry JP, Coon CN. Developmental changes of plasma insulin, glucagon, insulin-like growth factors, thyroid hormones, and glucose concentrations in chick embryos and hatched chicks. Poultry Science 2007:86:673-683

Maiorka A, Silva AVF, Santin E, Borges SA, Boleli IC, Macari M. Influência da suplementação de glutamina sobre o desempenho e o desenvolvimento de vilos e criptas do intestino delgado de frangos. Arquivo Brasileiro de Medicina Veterinária e Zootecnia 2000;52(5):487-490.

Ohta Y, Kidd MT, Ishibashi T. Embryos growth and amino acid concentration profiles of broiler breeder eggs, embryos and chicks after in ovo administration of amino acids. Poultry Science 2001;80(10):14301436.

Ohta Y, Tsushima N, Koide K, Kidd MT, Ishibashi T. Effects of amino acid injection in broiler breeder eggs on embryonic growth and hatchability of chicks. Poultry Science 1999;78(11):1493-1498.

Ohta Y, Yoshida T, Tsushima N. Comparison between broilers and layers for growth and protein use by embryos. Poultry Science 2004;83(5):783787

Pedroso AA, Chaves LS, Café MB, Leandro NSM, Stringhini JH, Menten JFM. Glutamine as broilers embryos nutrient. Brazilian Journal of Poultry Science 2006;8:43-49.

Ray EC, Avissar NE, Vukcevic D, Toia L, Ryan CK, Berlanga-Acosta J, et al. Growth hormone and epidermal growth factor together enhance amino acid transport systems $B$ and $A$ is Remnant small intestine after massive enterectomy. Journal of Surgical Research 2003;115(1):164170.

Salmanzadeh M, Ebrahimnezhad Y, Shahryar HA, Ghaleh-Kandi JG. The effects of in ovo feeding of glutamine in broiler breeder eggs on hatchability, development of the gastrointestinal tract, growth performance and carcass characteristics of broiler chickens. Archives Animal Breeding 2016:59:235-242.

Santos TT, Corzo A, Kidd MT, McDaniel CD, Torres Filho RA, Araújo LF. Influence of in ovo inoculation with various nutrients and egg size on broiler performance. Journal of Applied Poultry Research 2010;19:112

Silva AVF, Borges SA, Maiorka A, Giviziez PEN, Rocha C, Macari M. Ornitine decarboxylase expression in the small intestine of broilers submitted to feed restriction and glutamine supplementation. Brazilian Journal of Poultry Science 2007;9(2):111-116

Solberg DH, Diamond JM. Comparison of different dietary sugars as inducers of intestinal sugar transporters. American Journal of Physiology 1987;252(4):574-584 
Tako E, Ferket PR, Uni Z. Effects of in ovo feeding of carbohydrates and $\beta$-hydroxy- $\beta$-methylbutyrate on the development of chicken intestine. Poultry Science 2004;83(12):2023-2028

Torras-Llort M, Soriano-Garcia JF, Ferrer R, Moreto M. Effect of a lysineenriched diet on L-lysine transport by the brush-border membrane of the chicken jejunum. American Journal of Physiology 1998;274(1):6975.

Uni Z, Ferket P, inventor; Yissum Research Development Company Hebrew University, assignee. Enhancement of development of oviparous species by in ovo feeding. Regular Patent United State 6,592,878 B2. 2003.

Uni Z, Ferket PR, Tako E, Kedar O. In ovofeeding improves energy status of late-term chicken embryos. Poultry Science 2005;84(5):764-770.

Vieira BS, Faria Filho DE, Torres KAA, Borges DM, Rosa PS, Furlan RL. Administração in ovo de glutamina e de lisina sobre o desenvolvimento da mucosa intestinal de frangos na primeira semana pós-eclosão. ARS Veterinaria 2006;22(3):242-247.

Vieira SL, Moran Jr ET. Eggs and chicks from broiler breeders of extremely different age. Journal of Applied Poultry Research 1998;7(2):372-376.

Welborne TC. Increased plasma bicarbonate and growth hormone after an oral glutamine load. American Journal of Clinical Nutrition 1995;61(5):1058-1061.

Xu G, Kwon G, Marshall CA, Lin TA, Lawrence JC, McDaniel ML. Branched-chain amino acids are essential in the regulation of PHASand p70 S6 kinase by pancreatic $\beta$-cells. The Journal of Biological Chemistry1998;273(43):28178-28184.

Yi GF, Allee GL, Knight CD, Dibner JJ. Impact of glutamine and oasis hatchling supplement on growth performance, small intestinal morphology, and immune response of broilers vaccinated and challenged with Eimeria maxima. Poultry Science 2005;84:283-293. 
